\title{
Chemical Characteristics of Buffer Zone Sediments And Implications on Adjoining Water in Diyawanna Lake
}

\author{
A.A.S.D. Dias*, D.T. Jayawardana \\ ${ }^{I}$ Department of Forestry and Environmental Science, University of Sri Jayewardenepura, Sri Lanka \\ *samudias24@gmail.com
}

\begin{abstract}
Diyawanna Lake is one of the major fresh water body located in the middle of Sri Jayewardenapura Kotte. Most of surrounding area of the lake consists of marshlands. During the recent past several reclamation and development activities going on around the lake. In addition, sediments from surface runoff are finally accumulating in the lake margin (buffer zone). However, there is no any study done on sediment quality and impacts of them on adjoining water, especially in the buffer zone of such a fresh water body. Therefore, main aim of this study is to investigate quality of the sediment accumulated in the buffer zone of the lake and also to study the possible impacts on lake water from the sediments due to biogeochemical reactions in the zone. Thirty three water samples were collected during dry period and samples were analysed for $\mathrm{pH}$, electrical conductivity (EC), oxidation reduction potential (ORP), salinity, total dissolved solid (TDS), $\mathrm{NO}_{3}^{-}, \mathrm{PO}_{4}{ }^{3-}, \mathrm{SO}_{4}{ }^{2-}, \mathrm{Cl}^{-}$, alkalinity, hardness, $\mathrm{Na}, \mathrm{K}, \mathrm{Ca}, \mathrm{Mg}, \mathrm{Cd}, \mathrm{Cr}, \mathrm{Cu}, \mathrm{Fe}, \mathrm{Pb}, \mathrm{Mn}, \mathrm{Zn}$ and $\mathrm{Ni}$. In addition, black organic sediment samples were collected from selected locations and tested for $\mathrm{pH}$, ORP, EC, organic carbon, total organic matter, $\mathrm{NO}^{-3}, \mathrm{PO}_{4}^{-3}, \mathrm{Na}, \mathrm{K}, \mathrm{Ca}, \mathrm{Mg}, \mathrm{Cd}, \mathrm{Cr}, \mathrm{Cu}, \mathrm{Fe}, \mathrm{Pb}, \mathrm{Mn}, \mathrm{Zn}$ and $\mathrm{Ni}$. Average values of $\mathrm{pH}, \mathrm{EC}, \mathrm{ORP}, \mathrm{TDS}, \mathrm{NO}_{3}{ }^{-}, \mathrm{PO}_{4}{ }^{3-}, \mathrm{SO}_{4}{ }^{2-}, \mathrm{Cl}^{-}$, alkalinity, hardness, $\mathrm{Na}, \mathrm{K}$, $\mathrm{Ca}, \mathrm{Mg}, \mathrm{Cu}, \mathrm{Zn}$ and $\mathrm{Fe}$ for the lake water are 7.4, $222 \mu \mathrm{S} / \mathrm{cm},-37 \mathrm{mV}, 222 \mathrm{mg} / \mathrm{l}, 0.11 \mathrm{ppm}$, 15.00 ppm, 1.43 ppm, 20.00 ppm, 0.0002 ppm, 772 ppm, 16 ppm, 10 ppm, 36 ppm, 21 ppm, $0.001 \mathrm{ppm}, 0.009 \mathrm{ppm}$ and $0.14 \mathrm{ppm}$ respectively. However, element $\mathrm{Cd}, \mathrm{Pb}, \mathrm{Mn}$ and $\mathrm{Ni}$ were not detected. Piper classification for the lake water indicate $\mathrm{CaSO}_{4}$ type, which reflect typical gypsum type of waters with impact of mine drainage due to mineral pyrite in soil. Also, sulfur emitted by the vehicles may react with water to form sulfuric acid. In addition, gypsum type of water may also due to accumulation of building materials such as cement. Therefore reason for the $\mathrm{CaSO}_{4}$ type of water may be due to several sources in the area. In addition, compared to WHO guidelines only $\mathrm{Cr}(0.58 \mathrm{ppm})$ present in the water is considerably high, this may be due to direct discharge of urban dust into the lake. Average values of $\mathrm{pH}(6.1)$, ORP $(54 \mathrm{mV}), \mathrm{EC}(122 \mu \mathrm{S} / \mathrm{cm})$, organic carbon $(3.1 \%)$, total organic matter (18\%), nitrate (0.93 ppm), phosphate (12 ppm), $\mathrm{Na}(3.5 \mathrm{~g} / \mathrm{kg}), \mathrm{K}(11 \mathrm{~g} / \mathrm{kg}), \mathrm{Ca}$ (73 mg/kg), Mg (84 mg/kg), Cd (40 mg/kg), Cr (391 mg/kg), Cu (134 mg/kg), Fe (44 g/kg), $\mathrm{Pb}(833 \mathrm{mg} / \mathrm{kg}), \mathrm{Mn}(157 \mathrm{mg} / \mathrm{kg}), \mathrm{Ni}(196 \mathrm{mg} / \mathrm{kg})$ and $\mathrm{Zn}(33 \mathrm{~g} / \mathrm{kg})$ in the sediments are considerably different value than the water. Compare with Canadian Environment Quality guidelines average values of $\mathrm{Cd}, \mathrm{Cr}, \mathrm{Pb}$ and $\mathrm{Zn}$ are higher in the sediments. This is mainly due to accumulation of those elements from runoff water. In general, it can be concluded that prevailing physical conditions of the lake water is controlling leaching of heavy metals from sediments to water. Conversely, anthropogenic sources seem to be increase accumulation of heavy metals in the buffer zone sediments.
\end{abstract}

Keywords: Diyawanna Lake, Water quality, Sediment quality

Proceedings of the International Forestry and Environment Symposium 2015 of the Department of Forestry and Environmental Science, University of Sri Jayewardenepura, Sri Lanka 